\title{
A Light and Electron Microscope Study on the Phagocytosis of Leucocytes in Rockfish and Rainbow Trout
}

\author{
Kunio SUZUKI* \\ (Accepted December 14, 1983)
}

\begin{abstract}
Identification and characterization of leucocytes in two teleosts, rockfish Sebastes schlegeli and rainbow trout $S$ almo gairdneri were performed based on their morphology and phagocytic ability with bacteria, Escherichia coli and Staphylococcus aureus and zymosan particles. Cytochemical test for peroxidase was also applied to the leucocytes.

Light and electron microscopy revealed that both neutrophils and monocytes in the two teleosts actively phagocytized bacteria. Thrombocytes ingested bacteria, but their phagocytic activity was very low.

The process of phagocytosis was observed with neutrophils and monocytes. Fusion of cytoplasmic granules into phagosomes was observed. Large phagosomes were present in neutrophils but entirely (rockfish) or almost absent (rainbow trout) in monocytes. Cytoplasmic granules in neutrophils of both fishes were positive for peroxidase. The peroxidase reaction product was also observed in phagosomes. Therefore, the process of phagocytosis was considered to be similar to that known with mammalian leucocytes.

The fate of bacteria phagocytized by fish leucocytes differed to that in mammals. At even $12 \mathrm{~h}$ (rockfish) or $6 \mathrm{~h}$ (rainbow trout) after incubation, bacteria in phagosomes were almost intact and they seemed to be digested slowly compared with those ingested in mammalian leucocytes.
\end{abstract}

The phagocytic activity of leucocytes plays an important role in the defense mechanism in animals. The phagocytic process in mammalian leucocytes has been extensively studied for all cell types from cyto- and immunochemical as well as fine structural viewpoints. ${ }^{1-4)}$

Only a few works are available as to phagocytosis of leucocytes in teleosts. WATson et al. ${ }^{\mathrm{b}}$ reported that leucocytes in the circulating blood of goldfish Carassius auratus engulfed bacteria. WEINREB and WEINREB ${ }^{8)}$ and MORI ${ }^{7}$ observed phagocytosis of leucocytes in goldfish after intraperitoneal injection of Thorotrast and incubation with bacteria. FerGuson ${ }^{8)}$ observed that leucocytes of plaice Pleuronectes platessa phagocytize intravenously injected carbon particles. However, as recently ELLIs ${ }^{\text {B) }}$ has criticized the criteria for classification of fish blood cells, it is considered that identification and characterization of the cells involved in the phagocytosis in these studies should be reviewed by electron microscopic examination of the phagocytic process.

The present study was undertaken to characterize teleost leucocytes with regard to their phagocytic ability. The process of phagocytizing bacteria or zymosan particles was observed for cells in the circulating blood of rockfish and rainbow trout. Leucocytes in progressive stages of phagocytizing bacteria and zymosan particles were observed by light and electron microscopy. Cytochemical test for peroxidase was also applied to the leucocytes to examine the chemical nature of cytoplasmic granules and their participation in phagocytosis.

\section{Materials and Methods}

Adult rockfish Sebastes schlegeli, weighing $500-1500 \mathrm{~g}$, and rainbow trout Salmo gairdneri, weighing $200-300 \mathrm{~g}$, were used. The rockfish were kept in indoor tanks with running sea water at the Hokkaido Institute of Mariculture. The rainbow trout were purchased from a commercial hatchery and kept in an outdoor pond on campus.

Fish were anesthetized with MS-222 diluted 1: 10000 with sea water or fresh water. Blood was drawn into a disposable plastic syringe by pricking the duct of Cuvier in rockfish, or collected in a test tube by severing the caudal peduncle in rainbow trout. Heparin-Na was added to the blood (100 I. U. $/ \mathrm{m} l)$ to protect against coagulation.

The heparinized blood was transferred to $0.5 \mathrm{~m} l$

* Laboratory of Physiology and Ecology, Faculty of Fisheries, Hokkaido University, Minato, Hakodate 041, Japan（鈴木邦夫：北海道大学水産学部生理学生態学諈座)。 
Table 1. Percentage of phagocytizing neutrophils and monocytes of rockfish Sebastes schlegeli, when the blood was incubated with $E$. coli or $S$. aureus

\begin{tabular}{|c|c|c|c|c|}
\hline & & & & $n \pm S . D .(n=$ \\
\hline \multirow{2}{*}{$\begin{array}{l}\text { Incubation time } \\
\text { (h) }\end{array}$} & \multicolumn{2}{|c|}{ E. coli } & \multicolumn{2}{|c|}{ S. aureus } \\
\hline & Neutrophil & Monocyte & Neutrophil & Monocyte \\
\hline 2 & - & - & $\frac{3.5 \pm 0.7}{(0)^{*}}$ & $23.5 \pm 5.2$ \\
\hline 6 & $\begin{array}{c}9.3 \pm 0.2 \\
(33.4 \pm 0.4)\end{array}$ & $85.9 \pm 0$. & $\begin{array}{c}19.9 \pm 1.6 \\
(23.1 \pm 1.0)\end{array}$ & $93.4 \pm 0.5$ \\
\hline 12 & $\begin{array}{c}45.8 \pm 6.8 \\
(46.8 \pm 4.1)\end{array}$ & $93.5 \pm 1.7$ & $\begin{array}{c}44.1 \pm 3.8 \\
(26.3 \pm 0.2)\end{array}$ & $92.9 \pm 0.7$ \\
\hline
\end{tabular}

F: Fures in parentheses represent the percentage of neutrophils having one large phagosome.

Table 2. Percentage of phagocytizing neutrophils and monocytes of rainbow trout Salmo gairdneri, when the blood was incubated with $E$. coli or $S$. aureus

Mean \pm S.D. $(n=3)$

\begin{tabular}{cccccc}
\hline \multirow{2}{*}{$\begin{array}{c}\text { Incubation time } \\
(\mathrm{h})\end{array}$} & \multicolumn{2}{c}{ E. coli } & & \multicolumn{2}{c}{ S. aureus } \\
\cline { 5 - 6 } & Neutrophil & Monocyte & & Neutrophil & Monocyte \\
\hline 2 & $60.7 \pm 10.6$ & $52.1 \pm 0.3$ & & $63.3 \pm 1.8$ & $63.6 \pm 3.0$ \\
4 & - & - & & $(17.5 \pm 0.1)^{*}$ & \\
& & & & $(30.1 \pm 1.2$ & $87.8 \pm 0.7$ \\
6 & $74.7 \pm 5.6$ & $77.3 \pm 2.1$ & & $75.1 \pm 6.8$ & $83.4 \pm 4.6$ \\
& & & $(51.2 \pm 2.3)$ & \\
\hline
\end{tabular}

* Figures in parentheses represent the percentage of neutrophils having one large phagosome.

plastic tubes. A suspension of foreign material was added to the tube at one-tenth of the blood volume. It was then incubated while shaking at $15^{\circ} \mathrm{C}$ for $2-12 \mathrm{~h}$ in the case of rockfish, and at $15^{\circ} \mathrm{C}$ for $2-6 \mathrm{~h}$ in the case of rainbow trout. At 2, 4, 6 , 8 , and $12 \mathrm{~h}$ of incubation, the blood samples were processed for light and electron microscopy.

Escherichia coli, Staphylococcus aureus and zymosan (Zymosan A, Wako Pure Chemicals Ltd.) were used as foreign materials. Zymosan was used only for rainbow trout. The suspension added to the blood contained one of the foreign materials, either $2.7 \times 10^{8} / \mathrm{m} l$ of bacteria or $4 \times$ $10^{5} / \mathrm{m} /$ of zymosan, in physiological saline.

Blood smears for light microscopy were prepared in the usual way on a glass slide and stained with MAY-GIEMSA modified by YukI. ${ }^{10)}$ For electron microscopy, the blood samples were processed according to the method described by WATANABE et al., ${ }^{11}$ but slightly modified. Blood in a test tube was centrifuged at $1000 \mathrm{rpm}$ for 10 $20 \mathrm{~min}$. The plasma was decanted and replaced with $1.5 \%$ glutaraldehyde in $0.1 \mathrm{M}$ phosphate buffer (pH 7.4) containing 5\% sucrose. The test tube was left vertical for $1.5-3.5 \mathrm{~h}$ at $4^{\circ} \mathrm{C}$. The solidified buffy coat in a discoidal form was cut into several blocks, postfixed with $1 \%$ osmium tetroxide in $0.1 \mathrm{M}$ phosphate buffer containing $5 \%$ sucrose for $1 \mathrm{~h}$ at $4^{\circ} \mathrm{C}$, dehydrated in a series of graded ethanol and $Q Y-1$ and embedded in Epon 812. Ultra-thin sections were stained with uranyl acetate and lead citrate and examined with a Hitachi $\mathrm{H}-300$ electron microscope.

Some blocks before postfixation were incubated for peroxidase reaction in the medium of GRAHAM and KARNOVSKY, ${ }^{12)}$ which contained $0.05 \% 3,3^{\prime}-$ diaminobenzidine tetrahydrochloride, $0.01 \%$

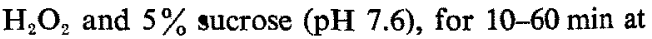
room temperature. The blocks were then processed for electron microscopy according to the procedures described above, except that the uitrathin sections were examined unstained.

\section{Results}

The main constituents of leucocytes in the circulating blood of rockfish are neutrophils, monocytes, thrombocytes and lymphocytes. ${ }^{13}$ The former three cell types were observed to phagocytize bacteria. At and after $2 \mathrm{~h}$ of incubation, neutrophils and monocytes ingested bacteria, both showing increasing numbers of phagocytizing cells as 


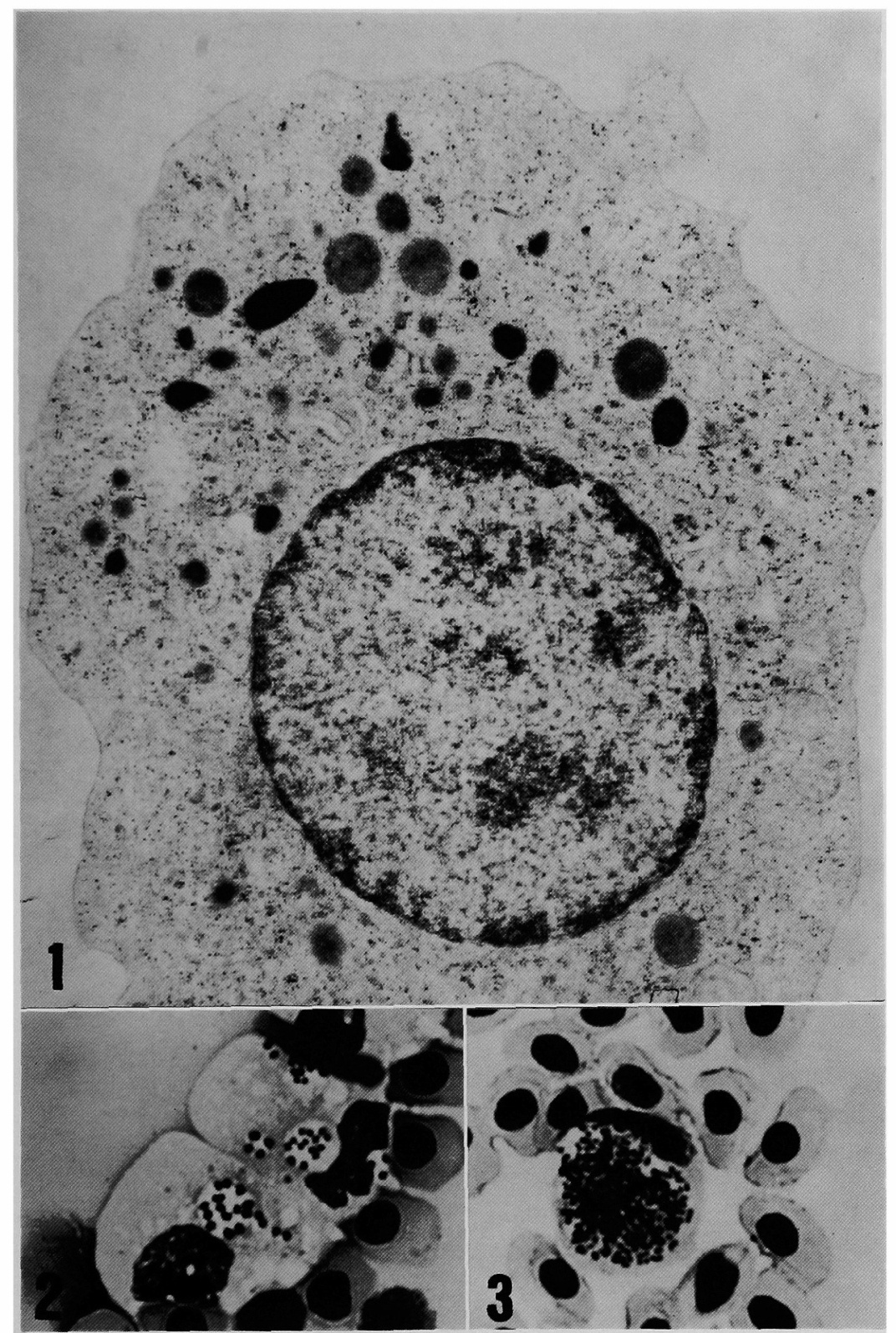

Fig. 1. Neutrophil of rockfish in non-phagocytic state. $\times 15,000$.

Fig. 2. Neutrophil of rockfish incubated with $S$. aureus for $6 \mathrm{~h}$. Light micrograph of a smear preparation. MAY-GIEMSA stain. $\times 1,700$.

Fig. 3. Neutrophil of rockfish incubated with $E$. coli for $12 \mathrm{~h}$. Light micrograph of a smear preparation. MAY-GIEMSA stain. $\times 1,700$.

the incubation time increased (Table 1). The percentage of phagocytizing cells was always higher in monocytes than in neutrophils. Thrombocytes which ingested bacteria were rarely observed.

Results obtained with rainbow trout were similar to those with rockfish, except that the percentage of phagocytizing neutrophils was almost the same as for monocytes (Table 2). Zymosan particles were phagocytized by both neutrophils and monocytes. The number of cells phagocytizing zymosan particles also increased with the incubation time. 


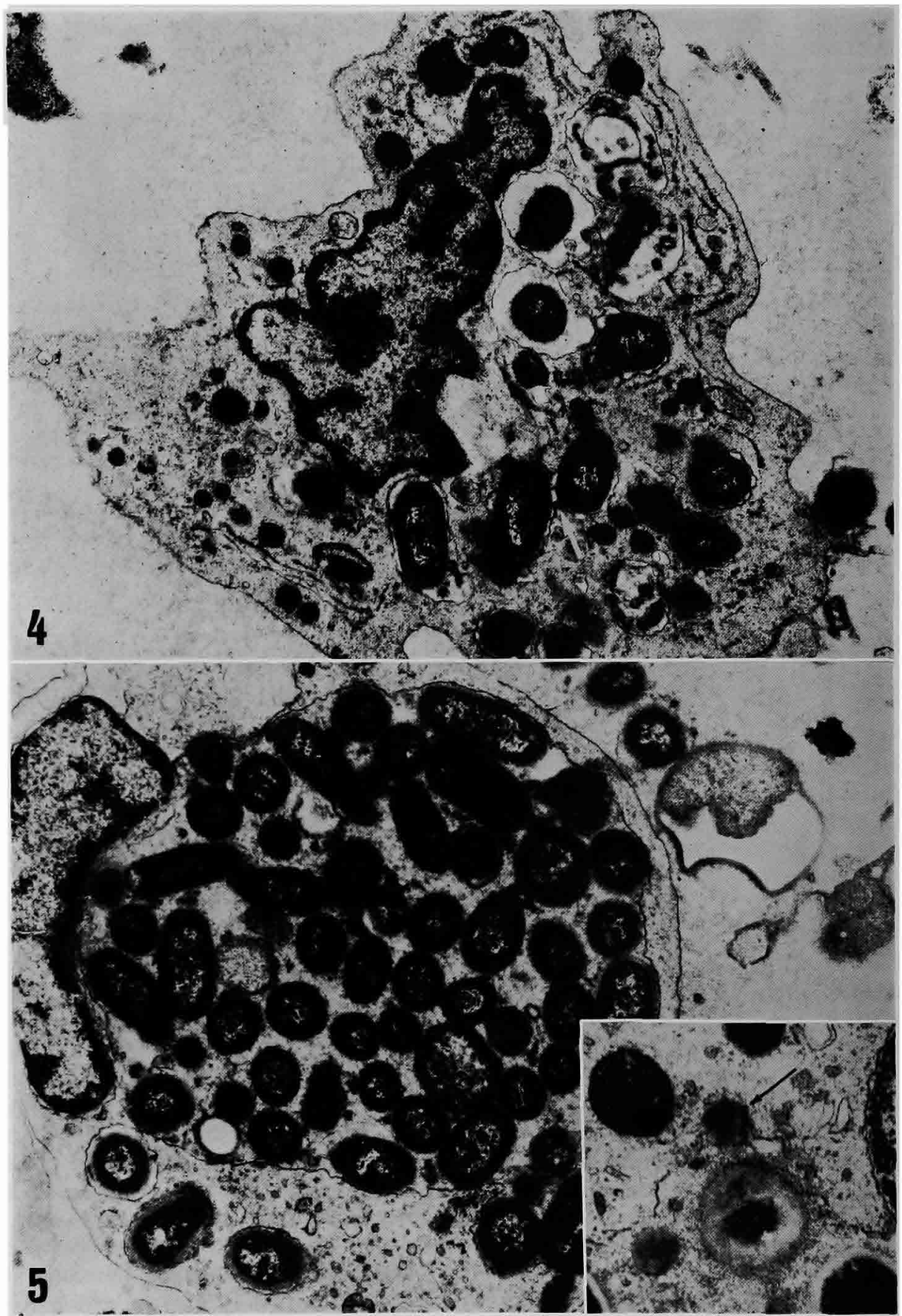

Fig. 4. Neutrophil of rockfish incubated with $E$. coli for 6 h. $\times 9,600$. Arrow indicates fusing of phagosomes. $\times 15,000$.

Fig. 5. Neutrophil of rockfish incubated with $E$. coli for $12 \mathrm{~h}$. $\times 11,000$. Inset depicts a granule (arrow) fusing with the phagosome membrane. $\times 22,000$. 


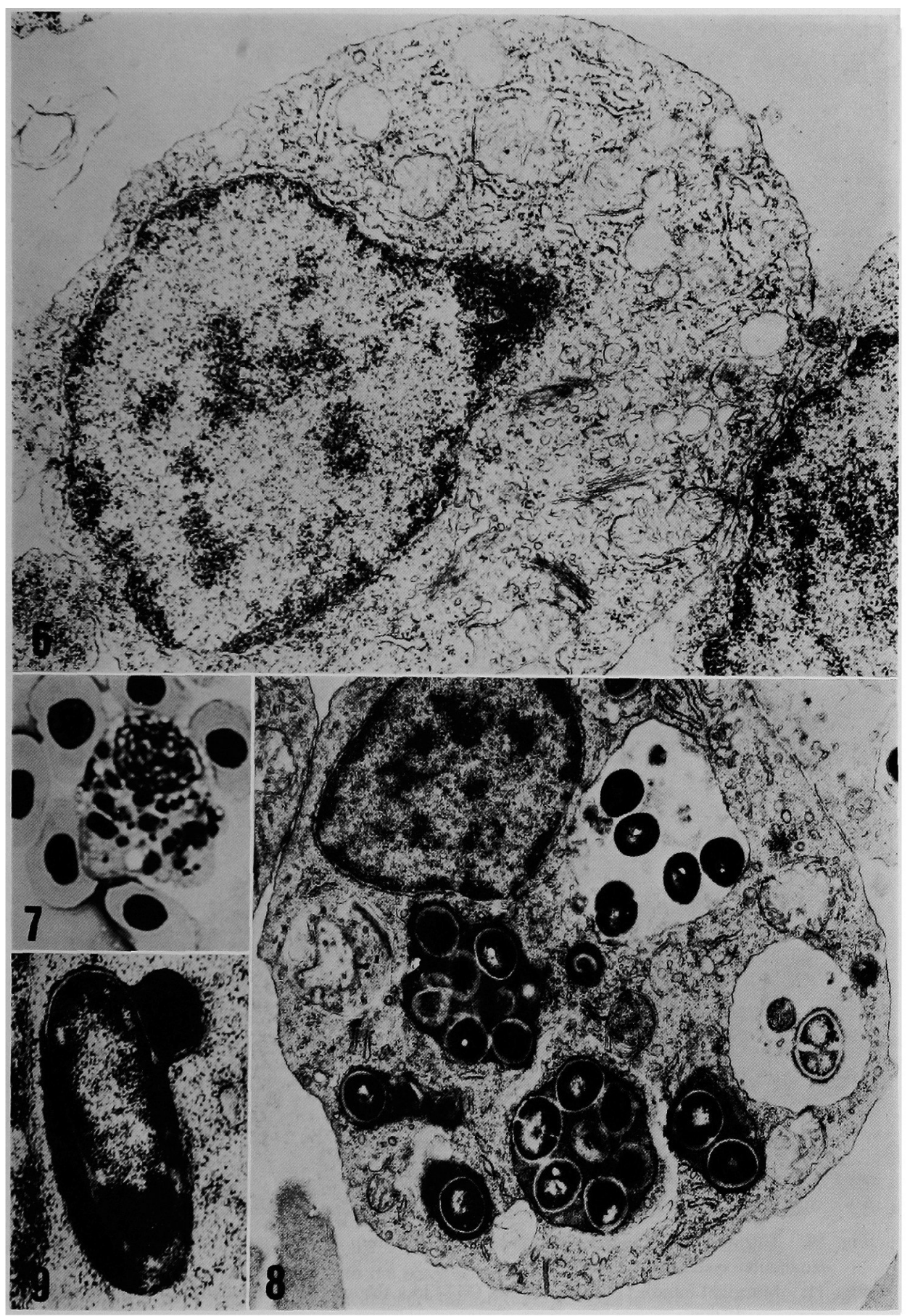

Fig. 6. Monocyte of rockfish in non-phagocytic state. $\times 9,700$.

Fig. 7. Monocyte of rockfish incubated with $S$. aureus for $6 \mathrm{~h}$. Light micrograph of a smear preparation. MAY-GiEMSA stain. $\times 1,700$.

Fig. 8. Monocyte of rockfish incubated with $S$. aureus for $4 \mathrm{~h} . \quad \times 7,800$.

Fig. 9. A granule fusing with the phagosome membrane in a monocyte of rockfish incubated with $E$. coli for $6 \mathrm{~h}$. $\times 27,000$. 


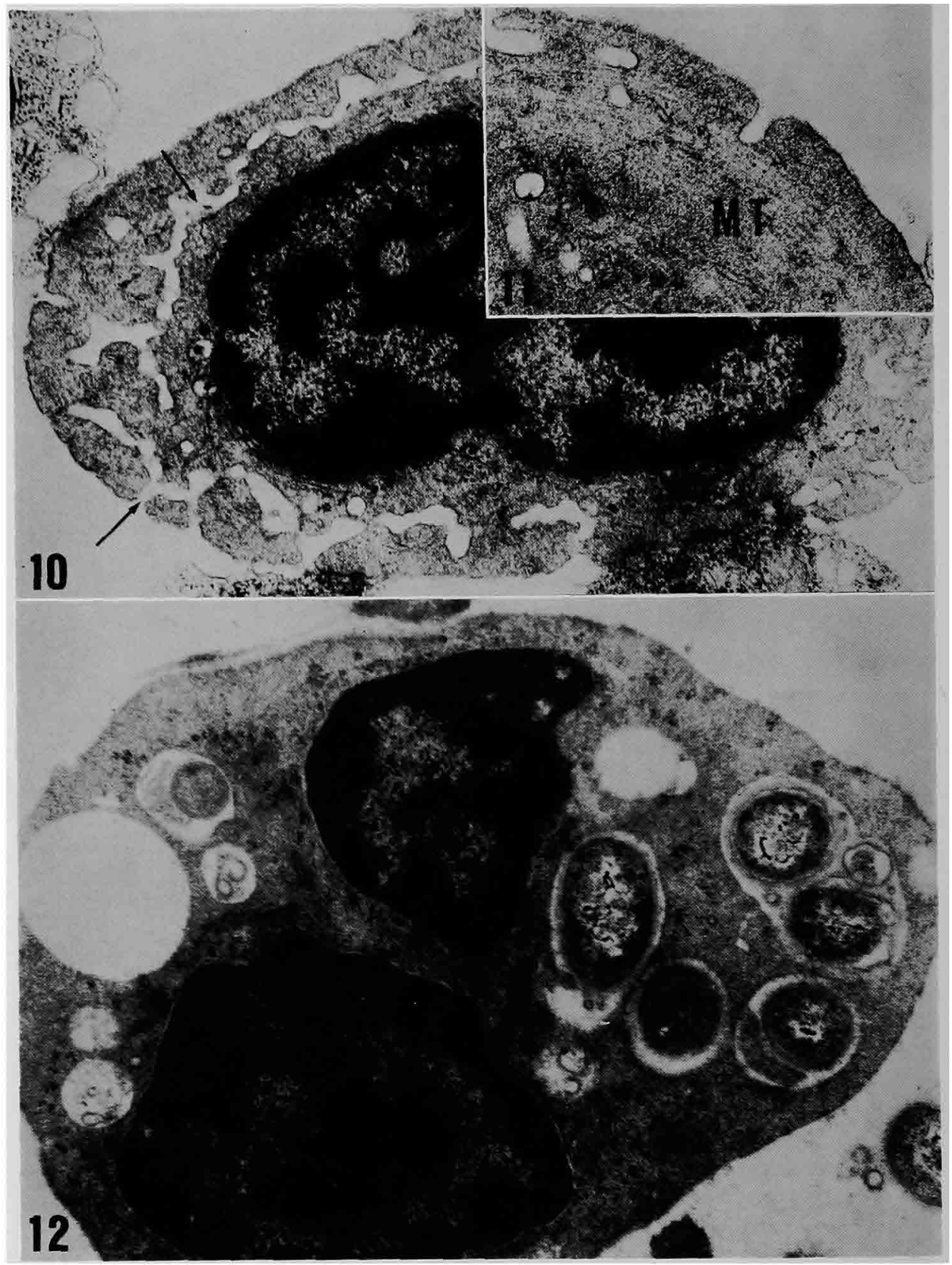

Fig. 10. Thrombocyte of rockfish in non-phagocytic state. Arrows indicate the surface connected canalicular system. $\times 25,000$.

Fig. 11. Marginal bundles of microtubules (MT) in a thrombocyte of rockfish in non-phagocytic state. $\times 27,000$.

Fig. 12. Thrombocyte of rockfish incubated with $E$. coli for $6 \mathrm{~h} . \quad \times 23,000$.

Fine structural aspects of phagocytizing leucocytes were almost the same in rainbow trout as in rockfish. Therefore, the process of phagocytosis was described mainly for rockfish leucocytes.
The neutrophils in the smears were 7.5-15.0 $\mu \mathrm{m}$ in diameter. The nucleus was usually round, oval or dumbbell shaped. The cytoplasm was glassy when stained with MAY-GIEMSA. A number of 


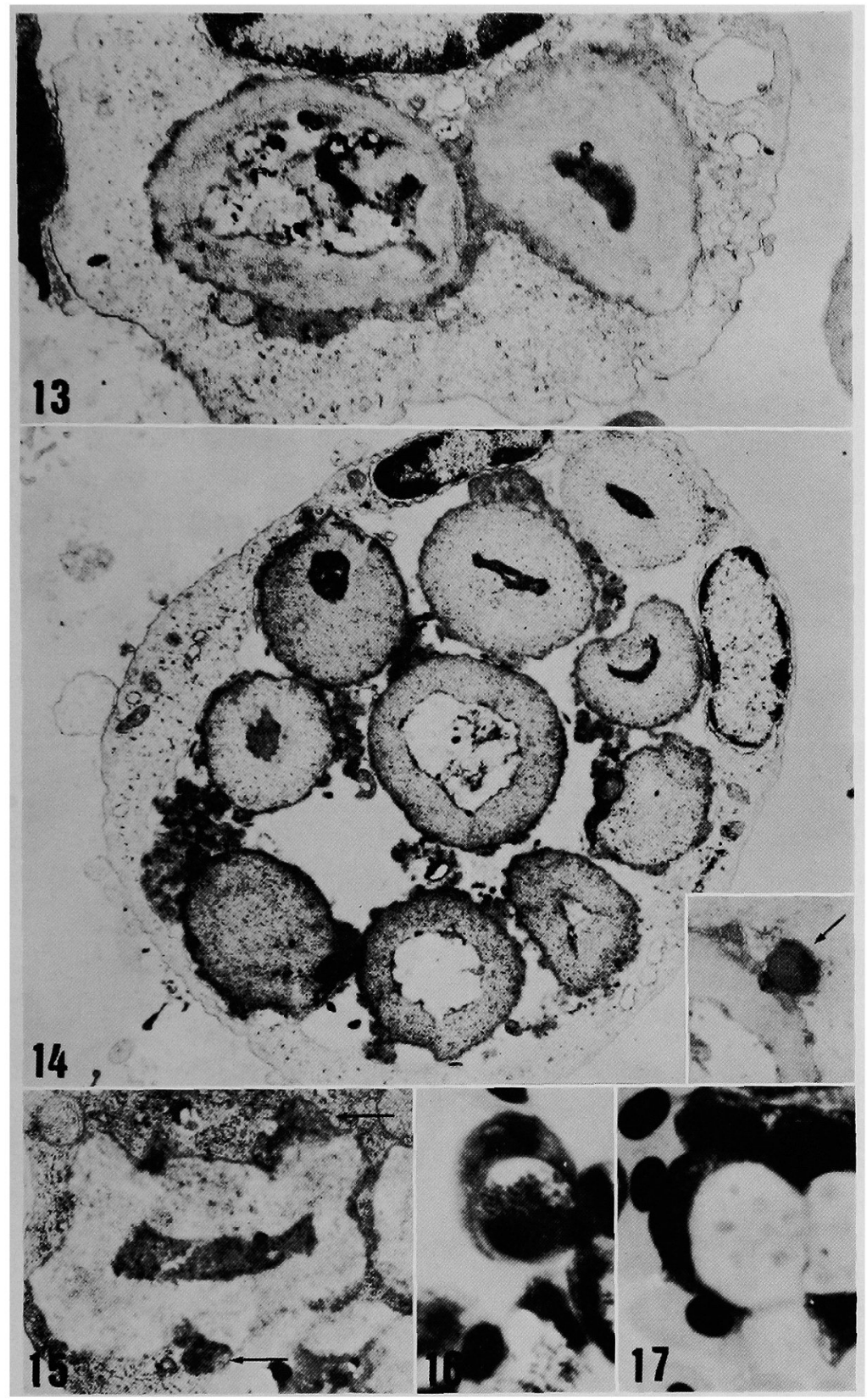

Fig. 13. Neutrophil of rainbow trout incubated with zymosan particles for $2 \mathrm{~h}, \quad \times 12,000$.

Fig. 14. Neutrophil of rainbow trout incubated with zymosan particles for $6 \mathrm{~h} . \quad \times 6,600$. Inset depicts a granule (arrow) fusing with the phagosome membrane. $\times 8,900$.

Fig. 15. Monocyte of rainbow trout incubated with zymosan particles for $6 \mathrm{~h}$. Arrows indicate granules fusing with the phagosome membrane. $\times 13,000$.

Fig. 16. Monocyte of rainbow trout incubated with $E$. coli for $6 \mathrm{~h}$. Light micrograph of a smear preparation. MAY-GIEMSA stain. $\times 1,400$.

Fig. 17. Monocyte of rainbow trout incubated with zymosan particles for $6 \mathrm{~h}$. Light micrograph of a smear preparation. MAY-GIEMSA stain. $\times 1,400$. 


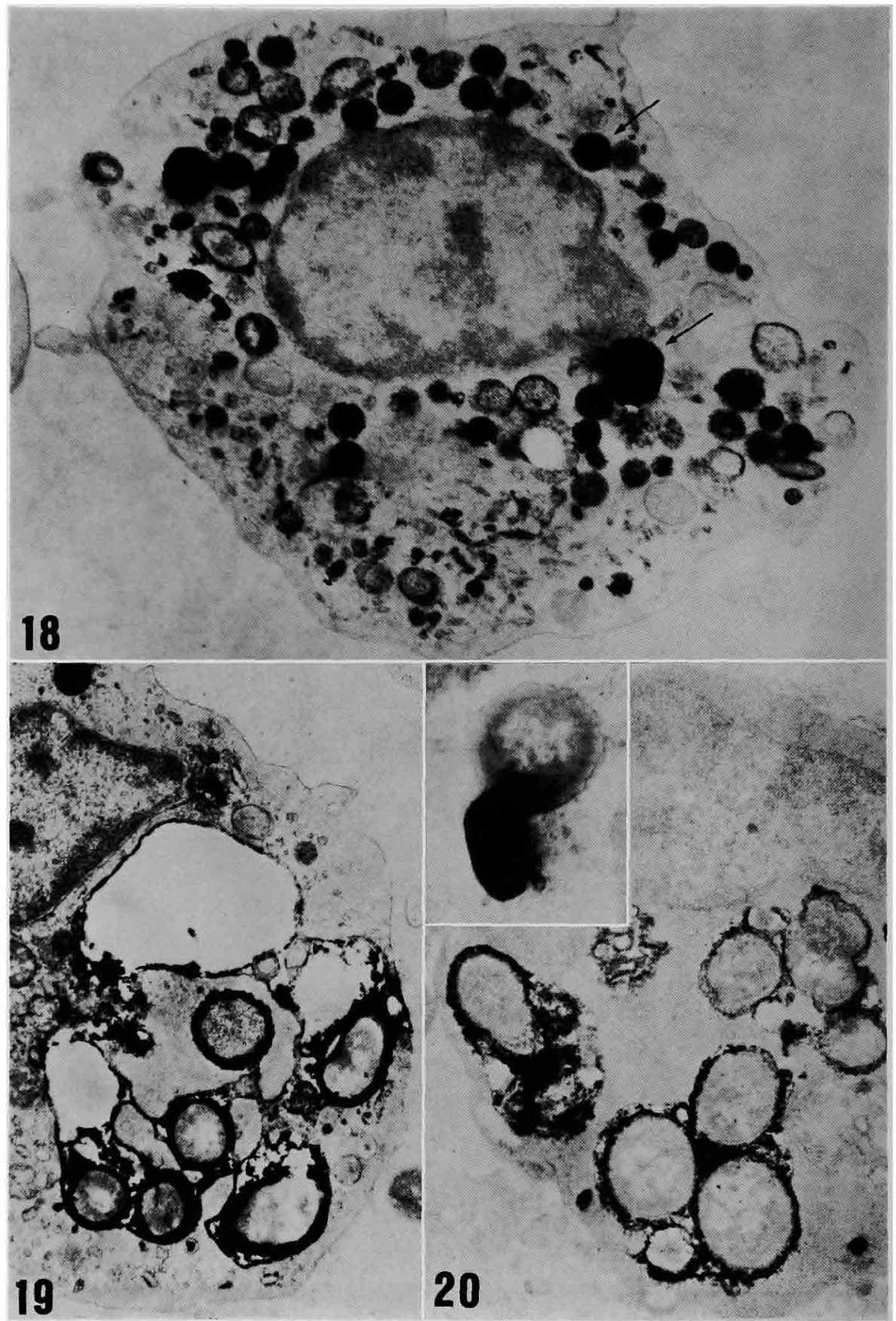

Fig. 18. Neutrophil of rockfish in non-phagocytic state. Peroxidase reaction. Arrows indicate peroxidase-positive granules. $\times 14,000$.

Fig. 19. Neutrophil of rockfish incubated with $E$. coli for 12 h. Peroxidase reaction. $\times 14,000$.

Fig. 20. Neutrophil of rainbow trout incubated with E. coli for 6 h. Peroxidase reaction. $\times 15,000$. Inset depicts a peroxidase positive granule fusing with the phagosome membrane. $\times 20,000$. 
granules of two types were found in the cytoplasm; one was oval or round, $0.1-0.6 \mu \mathrm{m}$ in diameter and electron dense, and the other was round, 0.2-0.4 $\mu \mathrm{m}$ in diameter and less dense. The rough and smooth endoplasmic reticuli and Golgi zones were not extensive and a few mitochondria were distributed in the cytoplasm (Fig. 1). The neutrophils incubated with bacteria contained one or more small phagosomes (Figs. 2 and 4) or one large phagosome which occupied almost the whole area of the cell (Figs. 3 and 5). $E$. coli and $S$. aureus were found to be engulfed by slender or broad pseudopodia after $2 \mathrm{~h}$ of incubation. At and after $6 \mathrm{~h}$, one or several small phagosomes appeared in the cytoplasm. The small phagosomes seemed to fuse together (Fig. 4 arrow). Fusion of granules of both types with the phagosome membrane was also observed (Fig. 5 inset). At and after $12 \mathrm{~h}$ of incubation, neutrophils usually had one large phagosome in which a number of bacteria were captured (Fig. 5). The nucleus was flat in shape and the cytoplasm contained few granules. Most bacteria in the large phagosomes looked intact even after $12 \mathrm{~h}$ of incubation. Only a few $S$. aureus had swollen cell walls and effluent cytoplasm, and only a few $E$. coli showed degraded features. Aside from the leucocytes, there were many bacteria, but only a few of which were degraded.

The monocytes in the smears were 5.0-15.0 $\mu \mathrm{m}$ in diameter. The nucleus occupied half or more of the cell volume. The cytoplasm was slate blue with a darker periphery when stained with MAY-GiEMSA. In the cytoplasm there were large mitochondria, extensive Golgi zones, developed rough endoplasmic reticulum sometimes in a concentric configuration and a few granules (Fig. 6). The granules were moderately dense and $0.3-0.6 \mu \mathrm{m}$ in diameter. Pseudopods were occasionally seen. Monocytes incubated with bacteria had only small phagosomes stained orange or violet with MAY-Giemsa (Fig. 7). Some bacteria inside the phagosomes were swollen or showed decreased stainability. In some monocytes phagosomes were not clearly seen. Foreign materials were ingested by pseudopods in the same fashion as by those in neutrophils. At and after $2 \mathrm{~h}$ of incubation, one or more small phagosomes each containing one or more bacteria were observed in the cytoplasm (Fig. 8). The phagosomes had granules attached to and fusing with the phagosome membrane, and contained a material of high density (Fig. 9). Phagosomes fusing together were rarely seen and there were no large phagosomes.

The thrombocytes were ovoid, spiked or ribbonlike in form. Electron microscopy revealed the so called surface connected canalicular system ${ }^{14)}$ (Fig. 10) and marginal bundles of microtubules (Fig. 11) in the cytoplasm. Bacteria ingested by thrombocytes were observed within small phagosomes (Fig. 12).

The neutrophils of rainbow trout had multilobed nuclei and the cytoplasm contained many small tubules (probably smooth endoplasmic reticulum) and rough endoplasmic reticulum, different from the neutrophils of rockfish. The monocytes and thrombocytes were similar in morphology to those of the rockfish except that they exhibited larger diameters. Bacteria and zymosan particles were ingested by rainbow trout leucocytes in a similar manner as rockfish leucocytes (Figs. 13, 14 and 15). Zymosan particles were not ingested in thrombocytes. Most of the zymosan particles in the phagosomes were intact or somewhat degraded at only the outermost part, even after $6 \mathrm{~h}$ of incubation (Fig. 14). Certain differences between the leucocytes of rockfish and of rainbow trout were observed. Phagosomes of rainbow trout neutrophils contained a material of low density which seemed to be released from granules attached to the phagosome membrane (Fig. 13), and phagosomes of rainbow trout monocytes were not stained deep orange or violet and were occasionally large (Figs. 16 and 17 ).

Cytoplasmic granules in neutrophils of both rockfish and rainbow trout were peroxidasepositive (Fig. 18). The peroxidase reaction product was detached in their phagosomes (Figs. 19 and 20) and in granules which were attached to the phagosome membrane (Fig. 20 inset).

\section{Discussion}

The present study reveals that both neutrophils and monocytes in rockfish and rainbow trout actively phagocytize bacteria without specific antiserum. Avtalion and ShaHrabani ${ }^{15}$ reported that in both the immune and non-immune circulating blood of carp Cyprinus carpio, the number of intracellular bacteria increased rapidly during the first $120 \mathrm{~min}$ of incubation. This phenomenon agrees with our results concerning the active phagocytization of bacteria by leucocytes without specific antiserum. However, SAKAI $^{16)}$ reported that peritoneal exudate cells of 
rainbow trout did not ingest bacteria, when incubated with Aeromonas salmonicida subsp. salmonicida without specific antiserum for $2 \mathrm{~h}$. This may be the result of different experimental conditions; in the present experiment the bacteria added were non-pathogenic and more abundant, and the incubation time was more than $2 \mathrm{~h}$.

The progressive stages of phagocytosis were similar to those reported with mammalian cells.") Cytoplasmic granules in mammalian neutrophils contain substances including peroxidase, acid and alkaline phosphatases which contribute to killing and digesting microorganisms and other foreign materials. ${ }^{17-20)}$ These granules degranulate and release the content into phagosomes. ${ }^{3,21)}$ This process is almost the same for monocytes. ${ }^{22,231}$ Teleost neutrophils are positive for acid phosphatase $^{13,24)}$ and their granules contain peroxidase ${ }^{253}$ and alkaline phosphatase. ${ }^{28)}$ Monocytes are also positive for acid phosphatase. ${ }^{13,24)}$ In mammalian neutrophils peroxidase occurs in primary lysosomes and participates in the myeloperoxidase-hydrogen peroxide-halide system which functions in killing microorganisms. 27) By analogy with the mammalian cells, some of the granules in teleost neutrophils and monocytes are presumed to be primary lysosomes and to participate in the killing and digesting of engulfed foreign materials.

The fate of bacteria phagocytized by neutrophils and monocytes in rockfish and rainbow trout differed from that in mammals. When human leucocytes were incubated with Staphylococci for $60 \mathrm{~min}$, the monocytes were considerably inferior to neutrophils in phagocytic and bactericidal activities, but the ability to destroy bacteria was similar. ${ }^{2)}$ Both the neutroohils and monocytes cultured at $15^{\circ} \mathrm{C}$ in the present study seemed to digest bacteria more slowly than in mammalian cells.

Phagosomes were formed differently for neutrophils and monocytes. Large phagosomes were observed mainly in neutrophils, and were entirely absent (rockfish) or almost absent (rainbow trout) in monocytes. This is believed to show that in monocytes fusion of small phagosomes rarely occurs, and that ingestion of foreign materials is not as active as in neutrophils. A functional difference may exist between neutrophils and monocytes as to phagocytic ability.

Ingestion of carbon or latex particles by fish thrombocytes has been reported by FERGUSON ${ }^{8)}$ and TAKAHASHI and DaIMON. ${ }^{28)}$ The present study shows that thrombocytes of rockfish and rainbow trout also ingest bacteria, but that their phagocytic activity is very low and that they seem not to function as phagocytes.

\section{Acknowledgments}

The auther is very grateful to Prof. J. Yamada, Laboratory of Physiology and Ecology, Faculty of Fisheries, Hokkaido University for his guidance and critical reading of this manuscript. Thanks are also due to Mr. M. Kusakari, Hokkaido Institute of Mariculture, for his help in obtaining material fish and Dr. K. TAzima, Laboratory of Microbiology of the same faculty for supply of bacteria and helpful advice.

\section{References}

1) D. Zacker-Franklin and J. G. Hirsch: $J$. Exp. Med., 120, 569-595 (1964).

2) Y. Kishigami: Acta Haem. Jap., 31, 973-983 (1968).

3) D. F. Bainton: J. Cell Biol., 58, 249-264 (1973).

4) F. M. Griffin, J. A. Griffin, J. E. LeIder, and S. C. Silverstein: J. Exp. Med., 142, 12631282 (1975).

5) L. Watson, I. L. Shechmeister, and L. L. JACKSON: Cytologia, 28, 118-130 (1963).

6) E. L. Weinreb and S. Weinreb: Zoologica, N. Y., 54, 25-34 (1969).

7) M. Mori: Fish Pathol., 16, 91-96 (1981).

8) H.W. Ferguson: J. Fish Biol., 8, 139-142 (1976).

9) A. E. Eluis: J. Fish Biol., 11, 453-491 (1977).

10) R. YUk1: Bull. Japan. Soc. Sci. Fish., 29, 10981103 (1963).

11) I. Watanabe, S. Donahue, and N. Hogatt: $J$. Ultrastr. Res., 20, 366-382 (1967).

12) R. C. Graham and M. J. Karnovsky; J. Histochem. Cytochem., 14, 291-302 (1966).

13) K. Suzuki, M. Kusakari, M. Shimizu, and J. YAMADA: Sci. Rep. Hokkaido Fish. Exp. St., 25, 201-215 (1983).

14) T. Darmon, V. Mizuhira, I. Takahashr, and K. UcHIDA: Cell Tissue Res., 203, 355-365 (1979).

15) R. R. Avtalion and R. Shamrabani: J. Immunol., 29, 1181-1187 (1975).

16) D. K. SAKaI: Sci. Rep. Hokkaido Fish Hatch., 36, 51-56 (1981).

17) B. K. Wetzel, S. S. SPICER, and R. G. HorN: J. Histochem. Cytochem., 15, 311-334 (1967).

18) D. F. Bainton and M. G. Farquhar: J. Cell Biol., 39, 286-298 (1968a).

19) D. F. Bainton and M. G. Farquhar: J. Cell Biol., 39, 299-317 (1968b).

20) M. S. Jensen and D. F. Bainton: J. Cell Biol, 56, 379-388 (1973). 
21) R. G. Horn, S. S. Silcer, and B. K. Wetzel: 24) A. E. Eluls: J. Fish Biol., 8, 143-156 (1976). Am. J. Pathol., 45, 327-335 (1964).

25) E. BIELEK: Cell Tissue Res., 220, 163-180 (1981).

22) B. A. Nichols, D. F. Bainton, and M. G. 26) C. Garavini, P Martelly, and B. Borelli: FARQUHAR: J. Cell Biol., 50, 498-515 (1971).

23) F. SchmalzL and H. Braunsterner: in "Mononuclear phagocytes" (ed. by R. VAN FURTH), Blackwell Sci. Publ., Oxford-Edinburgh, 1970. pp. 62-81. Histochem., 72, 75-81 (1981).

27) S. J. KleBANOFF: J. Exp. Med., 126, 1063-1078 (1967).

28) I. Takahashi and T. Daimon: Teikyo Igaku Zâshi, 2, 75-83 (1979). 